\title{
Federal Contributions to Postsecondary Education Under the Established Programs Financing: Trends and Implications**
}

\section{TERRY YUK SHING WU*}

\section{ABSTRACT}

This study reviews the federal funding of postsecondary education under the Established Programs Financing (EPF) arrangements introduced in 1977. Since 1977, federal transfers to the provinces for financing postsecondary education have increased in line with the growth rate of nominal gross national product, rather than in line with operating costs. This implies that the block funding arrangements have actually slowed the growth of federal contributions for the support of postsecondary education.

\section{RÉSUMÉ}

Cette étude examine le système du financement d'enseignement postsecondaire dans le cadre du financement des programmes établis (FPE) autorisés par la loi de 1977 en vertu des accords fiscaux entre le gouvernement fédéral et les provinces. Depuis 1977, les transferts fédéraux aux provinces, à titre du financement d'enseignement postsecondaire, ont augmenté en proportion du taux de croissance du produit national brut en terme réel plutôt qu' en proportion de la croissance des frais de fonctionnement des institutions postsecondaires. Ceci implique que le système de financement inconditionnel a, en somme, ralenti l'aide fédérale aux provinces.

\section{INTRODUCTION}

In recent years, universities and colleges across Canada have been faced with severe cutbacks due to inadequate funding from the provincial governments. These cutbacks have caused numerous financial problems to the postsecondary

*Department of Economics, University of Manitoba

**This paper draws partly on Chapter II of my doctoral dissertation (University of Manitoba). I would like to thank Professors James M. Dean and John A. Gray for their helpful comments on various earlier versions of the work. In addition, I am grateful to an anonymous referee for his useful comments on an earlier version of this paper. However, I am solely responsible for any errors that may remain. 
institutions, for examples: overcrowded classrooms, staff layoffs, reduced library hours, insufficient laboratory equipment, and, in some cases, even cancellation of programs. As a consequence, many postsecondary institutions have been forced to raise tuition fees and impose enrolment quotas in order to solve these financial problems. Faced with persistent protests from the students and the academic community in general, the provincial governments defend their positions by claiming that reduced fundings to postsecondary education are necessary because they do not receive sufficient transfer payments from the federal government. In order to understand the underlying cause of the financial problems of higher education, it is important to examine how the federal government has actually transferred funds to the provinces for financing postsecondary education.

This study is concerned with the federal contributions to postsecondary education under the Established Programs Financing (EPF) arrangements introduced in 1977. Prior to 1977, the federal funding of postsecondary education was financed by a conditional matching grant based on postsecondary operating costs (Boadway, 1980; Carter, 1982; Department of Finance, April 1981). Since 1977 , postsecondary education has been financed by a lump-sum block grant, in which the federal per capita contribution to the provinces increases in line with the growth of gross national product. The purpose of this study is threefold: first, to show how the federal contribution to postsecondary education is determined; second, to present the trends in federal contributions from an economic perspective; third, to discuss the implications of the block funding to postsecondary education.

\section{FUNDING ARRANGEMENTS UNDER THE ESTABLISHED PROGRAMS FINANCING}

In 1977, the federal government replaced the conditional cost-sharing federal transfers for postsecondary education with an unconditional grant as one of the components of the overall federal transfer payments to provinces on social programs. The Federal-Provincial Fiscal Arrangements and Established Programs Financing Act of 1977 provided a new method of financing the three established programs, namely hospital insurance, medicare and postsecondary education. The term "established programs" suggested that these social programs were by then well-established and the provinces were not likely to make major changes in their structures.

Under the new arrangements, the federal government contributed a lump-sum block grant covering these three social programs and replacing separate grants for each one of them. However, 32.1 percent of the federal transfers were allocated to postsecondary education, 50.5 percent to hospital insurance and 17.4 percent to medicare expenditures. ${ }^{1}$ The main characteristic of this new funding formula was that for all three programs federal contributions are determined independently of program costs in the provinces. Growth in the federal contribution was based on increases in the Gross National Product.

Like the previous cost-sharing arrangements, the block funding was fairly 
complex. The federal grant to the province consisted of both tax transfers and cash transfers. The tax transfer consisted of a federal reduction of one percent of the corporate income tax and 13.5 percent of the personal income tax, thus giving an equivalent amount of tax room to the provinces. Since the yields from the tax transfer differred widely from province to province, the tax points were equalized to the national average. ${ }^{2}$

The cash transfer was based on three different components. The first component was the "basic cash contribution" based on 50 percent of the national average per capita federal contributions to the three established programs in the base year $1975-76$, plus $\$ 7.63$ per capita. ${ }^{3}$ The latter amount represented the cash equivalent of one equalized personal income tax point per capita in 1975-76 in order to partly compensate provinces for the termination of the 1972 revenue guarantee program. ${ }^{4}$ The basic cash component was indexed to the growth of nominal per capita GNP and the growth of the province's population. ${ }^{5}$

The second component was the "transitional adjustment payment" which was equal to the difference between the basic cash contribution and tax transfers. If the value of the tax transfers fell short of the value of the basic cash contribution, then the province would receive the difference in the form of a cash payment. Hence, no province would lose by accepting part of the federal contribution in the form of tax transfer rather than in cash.

The third component was the "levelling adjustment payment" which aimed to eliminate the interprovincial disparities in the per capita federal contribution. Prior to the EPF arrangements, there were substantial differences in the base year per capita federal contribution among the provinces. Hence, a levelling adjustment was needed to smooth the transition from the previous shared-cost arrangements to the new block-funding arrangements. Provinces whose per capita federal contribution below the national average in the base year would be brought up to the national average in three years and the provinces above would be brought down to the national average in five years.

In fact, the EPF arrangements marked a new era of federal-provincial co-operation. The negotiations between the federal government and the provincial governments resulted in a satisfactory funding formula. The outcome of the fiscal arrangements actually involved a political compromise among the provinces. Initially, British Columbia and Alberta wanted the transfers all in tax points while the Atlantic provinces wanted the transfers all in cash. As a result of the compromise, the actual transfers were paid partly in cash and partly in tax points.

In 1982, the EPF arrangements remained largely unchanged when the initial five-year agreements were renewed after federal-provincial negotiations. ${ }^{6}$ The major change was that the total federal contributions to the three established programs for 1982-83 and subsequent years were equal to the national average per capita federal contribution in 1975-76 (not 50 percent as in the period from 1977 to 1982), multiplied by the growth of provincial population and GNP escalator. The value of cash transfers was determined by deducting the combined value of the transferred personal and corporate income tax points from the total fiscal transfers. 
In sum, the complexity of the old funding procedure was simplified, to a considerable extent, by the 1982 change.

In March 1983, the federal government announced that the annual growth of per capita federal contribution for postsecondary education would be limited to six percent in 1983-84, and to five percent in 1984-85. These restraints on federal transfers to postsecondary education were an extension of the federal government's "six and five" program introduced in June 1982 - a program that limited the wage increase of all civil servants and employees of the Crown corporations by six percent in 1982-83 and by five percent in 1983-84 in order to lower the rate of inflation.?

\section{FINANCING TRENDS}

This section presents the essential trends in federal funding of postsecondary education between 1977 and 1983. Table 1 shows the cash and tax transfers to the provinces with respect to postsecondary education for the fiscal year 1979-80. As can be seen from the figures in Table 1, the total cash transfers for all provinces exceeded the value of tax transfers for all provinces except Quebec and Alberta. Quebec received only 40.1 percent of the federal transfers in the form of cash, amounting to $\$ 298.2$ million. This was because Quebec opted out of the federal programs and received a special abatement of 8.5 personal income tax points for the EPF rather than cash transfers. The value of these points was subtracted from the cash transfers and added to the tax transfers in Quebec. With higher tax bases in the province, the richer provinces such as Ontario, Alberta and British Columbia ended up with a higher value of tax transfers. Since the tax points transferred were equalized to the national average, Newfoundland, Prince Edward Island, Nova Scotia, New Brunswick, Manitoba, and Saskatchewan all had 40.7 percent of the total federal contributions in the form of tax transfers. ${ }^{8}$

As mentioned earlier, the federal grant for postsecondary education was based on 32.1 percent of the EPF total transfers. ${ }^{9}$ Table 2 presents the annual federal grant to the provinces for postsecondary education under the EPF arrangements from 1977 to 1983. Total federal grants for postsecondary education increased from $\$ 2.1$ billion in 1977 to $\$ 3.64$ billion in 1983 , which represented an annual growth rate of 13 percent. Over the period 1977-83, the federal government transferred a total of $\$ 17.6$ billion to the provinces.

Table 3 shows the real federal transfers to postsecondary education from 1977-78 to 1982-83. In real terms, annual federal transfers to provinces were constant at $\$ 1.3$ billion since 1978-79. Thus, the annual national growth rate was only 1.3 percent from 1977 to 1983 . Between $1977-78$ and 1982-83, the federal government contributed a total of $\$ 8$ billion in 1971-72 constant dollars.

Real per capita federal transfers to postsecondary education from 1977-78 to 1982-83 is shown in Table 4. After the EPF was introduced in 1977, there were still large discrepancies in per capita grant among the provinces. In 1977-78, for example, Prince Edward Island received \$48.04 per capita while Quebec received $\$ 55.23$ per capita. From 1979 onwards, the per capita grant became more uniform 
TABLE 1

FEDERAL TRANSFERS TO POST-SECONDARY EDUCATION

FOR THE FISCAL YEAR $1979-80$

( in current thousands of dollars)

\begin{tabular}{|c|c|c|c|c|c|c|}
\hline & $\begin{array}{c}\text { Cash } \\
\text { Transfers }\end{array}$ & a $\%$ & $\begin{array}{c}\text { Tax } \\
\text { Transfers }\end{array}$ & b \% & $\begin{array}{c}\text { Total } \\
\text { Federal } \\
\text { Transfers }\end{array}$ & $\%$ \\
\hline $\begin{array}{l}\text { Nfld. } \\
\text { P.E.I. } \\
\text { N.S. } \\
\text { N.B. } \\
\text { Quebec } \\
\text { Ontario } \\
\text { Manitoba } \\
\text { Sask. } \\
\text { Alta. } \\
\text { B.C. }\end{array}$ & $\begin{array}{r}39,080 \\
8,461 \\
58,461 \\
48,075 \\
298,232 \\
554,804 \\
71,468 \\
66,116 \\
121,225 \\
154,790\end{array}$ & $\begin{array}{l}59.3 \\
59.3 \\
59.3 \\
59.3 \\
40.1 \\
55.7 \\
59.3 \\
59.3 \\
47.8 \\
51.1\end{array}$ & $\begin{array}{r}26,833 \\
5,811 \\
40,140 \\
33,011 \\
444,857 \\
440,827 \\
49,073 \\
45,398 \\
132,560 \\
148,376\end{array}$ & $\begin{array}{l}40.7 \\
40.7 \\
40.7 \\
40.7 \\
59.9 \\
44.3 \\
40.7 \\
40.7 \\
52.2 \\
48.9\end{array}$ & $\begin{array}{r}65,913 \\
14,272 \\
98,601 \\
81,086 \\
743,089 \\
995,631 \\
120,541 \\
111,514 \\
253,785 \\
303,166\end{array}$ & $\begin{array}{l}100.0 \\
100.0 \\
100.0 \\
100.0 \\
100.0 \\
100.0 \\
100.0 \\
100.0 \\
100.0 \\
100.0\end{array}$ \\
\hline Total ${ }^{c}$ & $1,425,025$ & 51.0 & $1,370,659$ & 49.0 & $2,795,684$ & 100.0 \\
\hline
\end{tabular}

Notes: ${ }^{2}$ The cash transfers include the basic cash contribution, the transitional adjustment payment and the levelling adjustment payment.

b Tax transfers consist of one percent of the corporate income tax and 13.5 percent of the personal income tax.

c These figures include federal grants to both yukon and Northwest Territories. Hence, this total is greater than the sum of all the provinces as shown in the Table.

Sources: Computed from the Department of the Secretary of State, Unpublished Data.

for all provinces except Alberta. As a result of the new 1982-87 EPF arrangements, the per capita real grant was equalized in all provinces in 1982-83. Interestingly enough, the per capita real grant declined in most provinces from $\$ 56$ in 1981-82 to $\$ 53$ in $1982-83$.

Table 5 shows the real federal contribution per full-time equivalent student. ${ }^{10}$ Full-time equivalent student is used instead of full-time student in this Table because part-time enrolment accounted for more than 20 percent of the total postsecondary enrolment. As shown in Table 5, there were large disparities in the real federal contribution per student among the provinces. In the first two years of the EPF arrangements, there were modest increases in the per student federal 
TABLE 2

ANNUAL FEDERAL TRANSFERS TO POST-SECONDARY EDUCATION

UNDER THE ESTABLISHED PROGRAMS FINANCING, 1977-83 ${ }^{\circ}$

(in current thousands of dollars)

\begin{tabular}{|c|c|c|c|c|c|c|}
\hline & $1977-7$ & $1978-79$ & $1979-80$ & $1980-81$ & $1981-82$ & $982-83$ \\
\hline $\begin{array}{l}\text { ask } \\
\text { ita } \\
\text {.c. }\end{array}$ & $\begin{array}{r}48,68 \\
9,9 \\
74,8 \\
59,5 \\
599,0 \\
767,1 \\
94,5 \\
83,0 \\
176,1 \\
217,1\end{array}$ & $\begin{array}{l}57 \\
12 \\
86 \\
70\end{array}$ & $\begin{array}{r}65,913 \\
14,272 \\
98,601 \\
81,086 \\
743,089 \\
995,631 \\
120,541 \\
111,514 \\
253,785 \\
303,166\end{array}$ & $\begin{array}{r}72,683 \\
15,802 \\
108,671 \\
89,514 \\
821,775 \\
1,102,378 \\
131,867 \\
123,574 \\
298,852 \\
348,393\end{array}$ & $\begin{array}{r}80,721 \\
17,419 \\
120,501 \\
99,025 \\
915,503 \\
1,226,440 \\
145,926 \\
137,688 \\
337,822 \\
394,171\end{array}$ & $\begin{array}{r}84,274 \\
18,181 \\
125,804 \\
103,358 \\
959,394 \\
1,284,854 \\
152,411 \\
144,726 \\
342,530 \\
414,708\end{array}$ \\
\hline $\mathrm{n}$. & 136,376 & 448,275 & 795,684 & $3,122,471$ & $3,485,303$ & $3,640,692$ \\
\hline
\end{tabular}

Notes: a. These figures include both cash and tax transfers.

b. This total includes federal grants to both Yukon and Northwest Territories. Hence this total is greater than the sum of all the provinces as shown in the Table.

Sources: Federal-Provincial Relations office, Federal-Provincial Programs and Activities.

Department of the Secretary of State, Annual Reports. Department of the Secretary of State, Unpublished Data.

contributions. From 1980-81 onwards, the federal contribution per full-time equivalent student declined gradually in all provinces. These declines in per student federal contribution were caused by the surge in postsecondary enrolment across the country since $1980-81$. Thus, it is not surprising to note that federal funds on a per student basis actually declined under the EPF arrangements because postsecondary enrolment was not taken into account in the calculations of the federal payments.

Figure 1 compares the rate of growth of real postsecondary education operating costs and real federal contributions to postsecondary education. One interesting point is that the growth rate of federal contributions actually declined after the EPF was introduced. At the same time, the growth rate of postsecondary education operating costs declined in the first three years but rose steadily in subsequent years. From 1980-81 onwards, the annual growth rate of operating costs exceeded that of federal contributions. The implication is that the growth of the EPF payment to postsecondary education did not keep pace with the operating costs. 
TABLE 3

REAL FEDERAL TRANSFERS TO POST-SECONDARY EDUCATION

UNDER THE ESTABLISHED PROGRAMS FINANCING, $1977-83^{a}$

( in constant thousands of dollars, 1971-72=100)

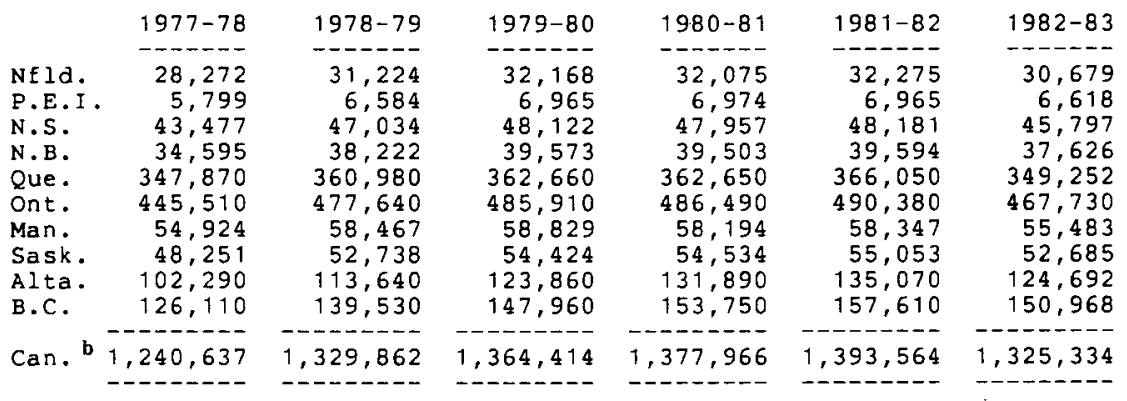

Notes: a. These figures include both cash and tax transfers,
using the GNE deflator for deflation.
b. This total includes federal grants to both Yukon and
Northwest Territories. Hence this total is greater
than the sum of all the provinces as shown in the Table.

Source: Computed from data in Table 2 and Statistics Canada, National Income and Expenditure Account.

From the above discussions, it is evident that the total federal contributions to postsecondary education in real terms were fairly constant over the six-year period between 1977 and 1983. As mentioned earlier, the EPF payment was determined by the growth of the economy rather than by the growth of the higher education costs. The surge in postsecondary enrolment in the last three years inevitably increased the operating costs of postsecondary institutions. This implies that the federal contributions actually fell behind the higher education costs. As a consequence, both the per capita and the per student federal contributions declined gradually since 1980-81.

\section{IMPLICATIONS}

The EPF arrangements had four budgetary implications. First, the new funding arrangements allowed the federal government to have a better control and a more accurate forecast of the amount of the transfers. This was because the federal funds were no longer tied to provincial expenditures on the basis of a 50:50 cost sharing formula. Increases in the operating expenditures in higher education did not lead to 
TABLE 4

REAL PER CAPITA FEDERAL TRANSFERS TO POST-SECONDARY EDUCATION, 1977-83 a

( in constant dollars, $1971-72=100$ )

\begin{tabular}{|c|c|c|c|c|c|c|}
\hline & $1977-78$ & $1978-79$ & $1979-80$ & $1980-81$ & $1981-82$ & $1982-83$ \\
\hline $\begin{array}{l}\text { NEld. } \\
\text { P.E.I. } \\
\text { N.S. } \\
\text { N.B. } \\
\text { Que. } \\
\text { Ont. } \\
\text { Man. } \\
\text { Sask. } \\
\text { Alta. } \\
\text { B.C. }\end{array}$ & $\begin{array}{l}50.35 \\
48.04 \\
52.05 \\
50.35 \\
55.23 \\
53.04 \\
53.34 \\
51.35 \\
52.56 \\
50.04\end{array}$ & $\begin{array}{l}55.49 \\
54.15 \\
55.99 \\
55.32 \\
57.09 \\
56.37 \\
56.77 \\
55.68 \\
56.29 \\
54.40\end{array}$ & $\begin{array}{l}56.99 \\
56.91 \\
57.04 \\
56.99 \\
56.99 \\
56.93 \\
57.34 \\
56.91 \\
59.04 \\
56.37\end{array}$ & $\begin{array}{l}56.61 \\
56.88 \\
56.63 \\
56.73 \\
56.56 \\
56.60 \\
56.81 \\
56.55 \\
60.17 \\
56.85\end{array}$ & $\begin{array}{l}56.65 \\
56.72 \\
56.68 \\
56.71 \\
56.72 \\
56.64 \\
56.67 \\
56.47 \\
59.39 \\
57.02\end{array}$ & $\begin{array}{l}53.50 \\
53.67 \\
53.48 \\
53.47 \\
53.83 \\
53.43 \\
53.34 \\
53.40 \\
53.37 \\
53.87\end{array}$ \\
\hline Can. b & 53.01 & 56.26 & 57.10 & 56.96 & 56.96 & 53.58 \\
\hline
\end{tabular}

Notes: a. These figures include both cash and tax transfers.

b. This total includes federal grants to both yukon and

Northwest Territories. Hence this total is greater than the sum of all the provinces as shown in the Table.

Sources: Computed from Table 3 and Statistics Canada,

Quarterly Estimates of Population for Canada and the Provinces.

a corresponding increase in federal transfers. As a consequence, the uncontrollable feature of the matching grants was eliminated.

Second, the financial arrangements gave the provinces more flexibility in the allocation of their own funds since the EPF payments were unconditional. The provinces were allowed to structure their own spending priorities over the various social programs according to their own preferences. Thus, the provinces might choose to spend a portion of the federal grant designated for postsecondary education on some other social programs that were more preferred by the provinces.

Third, the provinces were ensured greater equality in per capita grants under the block funding. Hence, the wide disparities in per capita grants among the provinces under the previous cost-sharing program were eliminated.

Finally, the new 1982-87 EPF arrangements led to revenue losses for the provincial governments on two grounds. First, under the new arrangements, the equalization associated with EPF tax transfers was deducted from the entitlement to determine the cash transfer (see Department of Finance, November 1981, pp. 
TABLE 5

REAL FEDERAL TRANSFERS PER FULL-TIME EQUIVALENT STUDENT ${ }^{a}$

( in constant dollars, $1971-72=100$ )

\begin{tabular}{lcccccc} 
& $1977-78$ & $1978-79$ & $1979-80$ & $1980-81$ & $1981-82$ & $1982-83$ \\
Nfla. & 2,851 & $-1,398$ & 3,286 & 3,119 & 2,849 & $-1,371$ \\
P.E.I. & 2,256 & 2,707 & 2,958 & 2,928 & 2,738 & 2,431 \\
N.S. & 1,863 & 2,053 & 2,122 & 2,064 & 1,989 & 1,752 \\
N.B. & 2,444 & 2,741 & 2,805 & 2,738 & 2,547 & 2,232 \\
Que. & 1,442 & 1,451 & 1,442 & 1,405 & 1,372 & 1,246 \\
Ont. & 1,807 & 1,945 & 1,921 & 1,833 & 1,758 & 1,572 \\
Man. & 2,201 & 2,455 & 2,555 & 2,441 & 2,287 & 1,980 \\
Sask. & 2,415 & 2,713 & 2,815 & 2,769 & 2,600 & 2,281 \\
Alta. & 1,962 & 2,196 & 2,389 & 2,472 & 2,384 & 1,989 \\
B.C. & 2,445 & 2,684 & 2,817 & 2,826 & 2,793 & 2,498 \\
\hline Can. & 1,807 & 1,928 & 1,949 & 1,900 & 1,836 & 1,635 \\
\hline
\end{tabular}

Notes: a. These transfers are calculated on a full-time equivalent basis. That is, full-time university and college students plus a full-time equivalent of part-time university students based on a conversion factor of 3 to 1 .

b. This total includes federal grants to both Yukon and Northwest Territories. Hence this total is greater than the sum of all the provinces as shown in the Table.

Source: Computed from data in Table 3 and Statistics Canada, Education in Canada.

45-47). Hence, the value of EPF cash transfer was reduced by including an associated equalization as an integral part of the calculations. Second, both the transitional and levelling adjustment payments were dropped as components of the cash transfer. ${ }^{11}$ If these payments disappeared in 1981-82, then their deletions would have no impact on the size of total federal transfer. In fact, no province received the levelling adjustment payments in the fiscal year 1981-82 (Department of Finance, 1983). On the other hand, the transitional adjustment payment did not disappear in 1981-82. Thus, the removal of the transitional adjustment payment in 1982 meant provinces received less than the amount they would have received under an extension of the old arrangements (Perry, 1983).

\section{CONCLUSIONS}

In conclusion, the escalating costs of higher education and the persistent provincial resistance to the shared-cost program subsequently persuaded the federal government to replace the conditional grant with the block grant. Prior to the block funding in 1977, provinces often complained about the federal intrusion into an 
Rate of Growth of Real Post-Secondary Education 0perating Costs and Real Federal Contributions to Post-Secondary Education, 1977-83

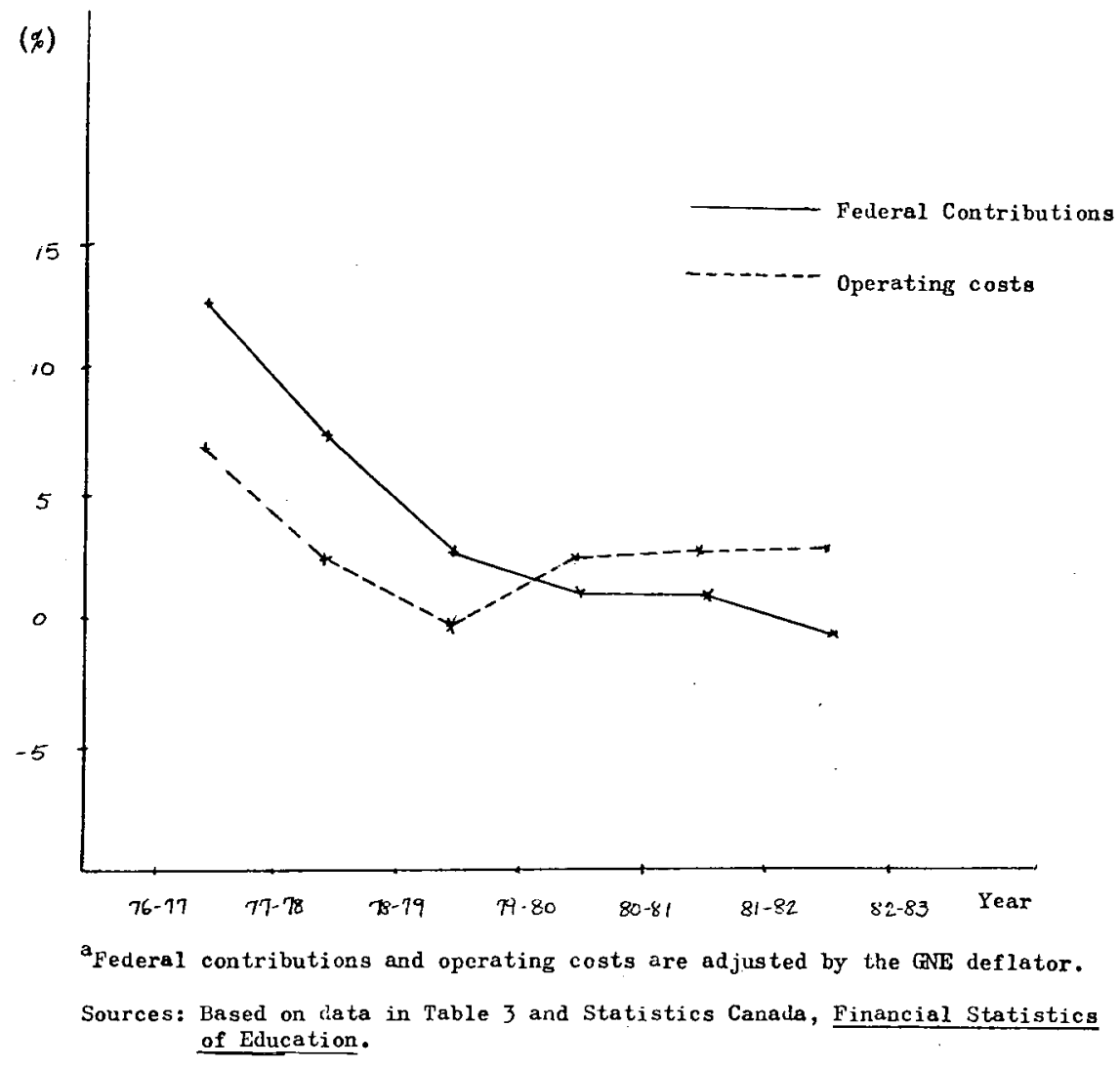

area of provincial jurisdiction; an intrusion which distorted their spending priorities. They also complained that the shared-cost programs caused them to spend more than they needed to spend in order to provide a given level of services. By providing provinces with greater flexibility with regard to program decisions under the EPF arrangements, the federal government has minimized provincial dissatisfaction on the one hand and has controlled costs of postsecondary education on the other.

The prospects for the federal funding of higher education in Canada will likely remain gloomy for the rest of the decade in light of the growing federal deficits. Obviously, the postsecondary portion of the EPF payments is a vulnerable target for the federal spending cuts since these transfers were not politically visible to the public. ${ }^{12}$ The renewed EPF arrangement in 1982 was a deliberate attempt by the federal government to reduce the federal transfers to the provinces (see 


\section{Department of Finance, November 1981). It is thus unlikely that the federal} government will restore funding increases in postsecondary education at this point in time, or even in the distant future. Given the continued federal reduction in the funding of postsecondary education, universities and colleges in Canada should expect further cutbacks in the years to come.

\section{NOTES}

1 It should be noted that the percentage allocation, which was based on the base year program costs of the three established programs, was only a national allocation. Since the provinces were not obliged to spend the designated 32.1 percent of the EPF transfers on higher education, they could therefore spend more or less than 32.1 percent of the EPF transfers on higher education if they preferred.

2 It should be noted that, in equalizing tax points, those provinces which had tax transfers below the national average were brought up to the national average, but those above were not brought down.

3 The rationale for choosing 1975-76 as an appropriate base year is that the year is recent enough to be relevant. Furthermore, the chances for provinces to overestimate the expenditures into the base year are assumed to be minimized as the year ended before negotiations began.

4 The revenue guarantee program introduced in 1972 was a five-year transition program to ensure that provinces would not lose personal or corporate tax revenues as a result of the 1972 tax reform. This is because the provincial personal income taxes collected under the tax collections agreements were expressed as a percentage of federal tax bases. If there was a tax reform, any changes in the federal tax rate or base could affect provincial tax collections. Hence, there was some uncertainty conceming the tax rates that the provinces would have to set to obtain equivalent revenues. Under the revenue guarantee program, the federal government would compensate a province revenue losses resulting from the tax reform. When the program was expired in 1977, the provinces asked for four points of personal income tax in compensation. The provinces settled for two personal income tax points, (one in cash, and the other one in tax transfers), which were added to the tax and cash contributions under the EPF arrangements. The cash equivalent of one equalized personal income tax point given to the provinces under the EPF arrangements was intended to persuade provinces to integrate the hospital insurance program into the EPF arrangements.

5 The growth of the nominal per capita GNP can be expressed by a three-year moving average of the GNP escalator. GNP escalator is simply the cube root of the per capita GNP of the previous year over the per capita GNP 4 years ago. Algebraically, the GNP escalator is defined by the following formula:

$$
\underset{\text { in year } t}{\text { GNP escalator }}=\sqrt[3]{\frac{\text { GNP per capita in year }(t-1)}{\text { GNP per capita in year }(t-4)}}
$$

It should be noted that the GNP per capita in both years $(t-1)$ and $(t-4)$ are measured in calendar year rather than in fiscal year.

6 The legislation requires the federal government to provide three years' notice in advance for any modifications or terminations of the EPF arrangements.

7 The "six and five" program was an incomes policy that the federal government introduced in order to influence wage and price formation in the economy. The limits on the wage increases of six percent in 1982-83 (from July 1982 to June 1983) and five percent in 1983-84 in the public sector provided a signal to the private sector to adopt a similar policy by limiting the wage increases by six and five percent in these consecutive years. Consequently, the wage and price increases in all sectors of economy were expected to go up by only six percent in the first year and five percent in the second year, thus lowering the expected rate of inflation (inflationary expectations). This would cause inflation rates to drop to the levels that were close to the six and five percent.

8 Initially, these provinces had per capita tax yields below the national average. Hence, the tax points transferred to these provinces were brought up to the national average.

9 The annual federal transfers are intended not to show the exact amount of funds allocated to postsecondary education by provinces, but rather to indicate the designated amount that the provinces are supposed to spend on higher education. 
10 Part-time enrolment is converted to full-time equivalent enrolment by using a factor of 3 to 1 (i.e. 3 part-time students to 1 full-time student).

11 It should be stressed that the changes made in 1982 were designed not only to simplify the complex EPF funding formula, but also to reduce federal payments to the three established programs at a time of fiscal restraint. In fact, the federal government projected that the new EPF funding formula could reduce federal payments to the three established programs by $\$ 5.7$ billion over the five-year period between 1982-83 and 1986-87 (Department of Finance, November 1981). This suggests that the federal government intended to cut back the transfer payments to the three established programs in order to reduce the federal deficits.

12 It should be noted that the cash component of the EPF transfer for postsecondary education is particularly vulnerable for federal cutbacks. This is because it is easier for the federal government to reduce the cash payment than to retract the tax transfer.

\section{REFERENCES}

Association of Universities and Colleges of Canada. Funding Canada's Universities in the 1980 s. Report on the Meeting of the Association of Universities and Colleges of Canada, Ottawa: Association of Universities and Colleges of Canada, 1982.

Boadway, R.W. Intergovernmental Transfers in Canada. Toronto: Canadian Tax Foundation, 1980.

Brown, M.C. Established Program Financing: Evolution or Regression in Canadian Fiscal Federalism? Research Monograph No. 38, Canberra: The Australian National University, 1984.

Canadian Association of University Teachers. Canadian Universities and the Federal Government. Mimeographed, 1980.

Canadian Association of University Teachers. The Funding of Canadian Universities. Mimeographed, 1981.

Canadian Association of University Teachers. Established Programme Funding. Newsletter, 1981.

Carter, G.E. Financing Health and Post-Secondary Education: A New and Complex Fiscal Arrangement. Canadian Tax Journal, 1977, 25(5), 534-550.

Carter, G.E. New Directions in Financing Canadian Federalism. Occasional Paper No. 13, Canberra: The Australian National University, 1980.

Carter, G.E. The Federal Impact on Financing Higher Education in Canada. Occasional Paper No. 25, Canberra: The Australian National University, 1982.

Courchene, T.J. Refinancing the Canadian Federation: A Survey of the 1977 Fiscal Arrangements Act. Montreal: C.D. Howe Research Institute, 1979.

Department of Finance. Established Programs Financing - Final Calculation. Ottawa: Queen's Printer, Various Issues.

Department of Finance. Established Programs Financing - Special Interim Adjustment 1981-82. Ottawa, Queen's Printer, 1983.

Department of Finance. Fiscal Arrangements in the Eighties - Proposals of the Government of Canada. Ottawa, Queen's Printer, November 1981.

Department of Finance. Federal-Provincial Fiscal Arrangements in the Eighties. A Submission to the Parliamentary Task Force on the Federal-Provincial Fiscal Arrangements by Allan J. MacEachen, Ottawa: Queen's Printer, April 1981.

Department of the Secretary of State. Annual Reports. Ottawa: Queen's Printer, Various issues.

Economic Council of Canada. Financing Confederation: Today and Tomorrow. Ottawa: Supply and Services Canada, 1982.

Federal-Provincial Relations Office. Federal-Provincial Programs and Activities. Ottawa, Queen's Printer, Various Issues.

Leslie, P.M. Canadian Universities 1980 and Beyond. Ottawa: Association of Universities and Colleges of Canada, 1980.

Nowlan, D.M. \& Bellaire, R. (ed.). Financing Canadian Universities: For Whom and By Whom? Toronto: OISE Press, 1981. 
Federal Contributions to Postsecondary Education under the

23 Established Programs Financing: Trends and Implications

Parliamentary Task Force on Federal-Provincial Fiscal Arrangements. Fiscal Federalism in Canada. Ottawa: Queen's Printer, 1981.

Perry D.B. Fiscal Figures. Canadian Tax Journal, 1981, 29(2), 246-251.

Perry, D.B. The Federal-Provincial Fiscal Arrangements for 1982-87. Canadian Tax Journal, 1983, 31(1), 30-47.

Social Science Federation of Canada. Principles and Mechanisms for the Financing of University Education and Research in Canada. Brief Submitted to the House Committee on Federal-Provincial Fiscal Arrangements on Behalf of the Social Science Federation of Canada, Ottawa, 1981.

Social Science Federation of Canada. Federal-Provincial Funding of Research and Universities: Proposals from the Social Science Federation of Canada of Issues of Established Programs Financing. Ottawa, 1982.

Statistics Canada. Education in Canada. (Cat. no. 81-229), Ottawa, Various Issues.

Statistics Canada. Federal Government Finance. (Cat. no. 68-211), Ottawa, Various Issues.

Statistics Canada. Financial Statistics of Education. (Cat. no. 81-208), Ottawa, Various Issues.

Statistics Canada. National Income and Expenditure Accounts. (Cat. no. 13-533), Ottawa, Various Issues.

Statistics Canada. Quarterly Estimates of Population for Canada and the Provinces. (Cat. no. 91-001), Ottawa, Various Issues.

Statistics Canada. University Financial Statistics. (Cat. no. 81-212), Ottawa, Various Issues. 